\title{
Capital Market Liberalization: Effect of Foreign Investors on Saudi Stock Market Performance
}

\author{
Abeer Faleh H. Almutiri \\ Science in Finance, Riyadh, Saudi Arabia \\ Email: Abeer.92f@hotmail.com
}

How to cite this paper: Almutiri, A.F.H. (2020) Capital Market Liberalization: Effect of Foreign Investors on Saudi Stock Market Performance. Journal of Mathematical Finance, 10, 267-286.

https://doi.org/10.4236/jmf.2020.102017

Received: August 7, 2020

Accepted: May 15, 2020

Published: May 18, 2020

Copyright $\odot 2020$ by author(s) and Scientific Research Publishing Inc. This work is licensed under the Creative Commons Attribution International License (CC BY 4.0).

http://creativecommons.org/licenses/by/4.0/ (c) (i) Open Access

\begin{abstract}
This study aims to determine if a cause exists between foreign investors BUY and SELL and the Saudi stock market performance. The dependent variable is Saudi stock index represented by INDEX while the independent variables are buying for foreign investors, selling for foreign investors namely BUY and SELL. The research period starts from January 2008 to December 2018. Unit root tests with structural breaks based on Augmented Dickey-Fuller unit root test and Zivot Andrew unit root test, Co-integration analysis, and Granger causality tests were used to test 4 hypotheses stating no effect on Saudi stock market of foreign buy and sell. Results indicate the importance of foreign investors BUY and SELL to explain stock market movements. The study will guide Saudi policymakers, analysts, and financial institutions to benefit from the clear link between investors selling and buying and Saudi stock performance paving the way for Wise policies.
\end{abstract}

\section{Keywords}

Saudi Stock Market, Foreign Investors, Unit Root Test, Structural Break, Co-Integration, Granger Causality

\section{Introduction}

\subsection{Background of the Study}

The historical beginnings of the Saudi stock market are due to 1932 when the first joint-stock company was established in the Kingdom Saudi Arabia, the Arab Automotive Company, later; other companies were established during the seventies of the Gregorian, as the number of these companies increased. As the number of shareholding companies grew, a non-market emerged of shares in the early 1980s, until the order was issued High No. 1230/8 in 1984 regulating trading; the task of supervising and implementing market activity was assigned rules 
governing the trading process to SAMA, the Saudi Arabian Monetary Agency [1].

Saudi market witnessed a new qualitative leap in the release of the financial market system in accordance with the Royal Decree. 30/M dated 31/7/2003, which restructured the regulatory and supervision of the capital market. And the creation of a financial and administrative independence body of Capital Market Authority is directly linked to the Chairman of the Board Ministers. It aims to regulate and develop the financial market in the Kingdom and has the authority to establish regulations and rules and instructions to implement the provisions of the Capital Market Law to protect investors, ensure fairness and efficiency in the stock market [1].

Given the vision of the Kingdom of Saudi Arabia 2030, the Capital Market Authority (CMA) and the Saudi Stock Exchange (Tadawul) carried out several major developments in the stock market and achieved several achievements to join the FTSE Emerging Markets Index announced in October 2017.

FTSE Russell launched the (FTSE Saudi Inclusion Index), a comprehensive series of global, regional and local indices that can be used as a transitional tool to help local and foreign investors who wish to identify the performance of the Saudi financial market through the index. On March 28, 2018, the FTSE Russell Group, the global index document, joined Tadawul to its global index [2].

Morgan Stanley Capital International (MSCI) has announced that it will begin listing Saudi Arabia in the Emerging Markets category, sharply expanding the country's investor base in a move that may be supportive of its equity market, with effect from mid the year of 2019, see [3].

Since its establishment, the CMA has adopted the principle of gradual opening up of the financial market to foreign investors, allowing foreign investors to acquire the economic benefits of Saudi shares through barter agreements in 2008 and thus direct access to markets through rules governing the investment of eligible foreign financial institutions in equities listed during 2015. CMA has relaxed restrictions on foreign investors. The reforms began on January 23, 2018, which would further ease restrictions, which include reducing the asset requirement maintained or managed by eligible foreign investors from $\$ 1$ billion to $\$ 500$ million and raising the percentage of ownership of any company from 5\% to $10 \%$ for foreign investors, raising the proportion of foreign ownership combined to $49 \%$ of the shares of any company [4].

The CMA will increase the overall attractiveness of the market to local and foreign investors by aligning their regulatory requirements with international best practice. The CMA hopes that the rise in foreign ownership in Saudi listed securities is achieving many desired benefits, including the promotion of institutional investment Market efficiency, transfer of knowledge and expertise to local financial institutions and investors, raising the profile of the Saudi market and its global classification, and increasing the level of research and assessments of companies and the public market [4]. 
Ghassan and Alhajhoj [5] (2012) paper have examined the volatility in the Saudi stock market by examining the structural transformations, based on a daily database for the period (2001-2010). The results highlight that the period of openness to domestic and foreign capital is characterized by a more important flow of information. Further, it is proved that the access of foreign investors could reduce the return volatility of TASI, Tadawul All Share Index.

From this point, the study examines the impact of foreign investors' behavior on the performance of the Saudi stock market after its liberation. ${ }^{1}$

\subsection{The Historical Beginnings of Foreign Investors Entrance}

The largest and most liquid in the Arab world, the $\$ 340$ billion market was off-limits to anyone outside the Gulf, Saudi Arabia has guarded its domestic market against foreigners and prevented overseas companies to enter into joint ventures with local merchants, and its' stock market.

Since Almost $\$ 500$ bn evaporated from the market's capitalization as a result of 2006 Saudi stock market crash, strategies to tame the Tadawul stock market's often wild fluctuations were implemented, and so that allowed international investors access the market [6].

The Program for Financial Sector Development 2020 has revealed that the program aims to raise the percentage of foreign investors' ownership of the total market capitalization of shares from $4 \%$ in 2016 to $15 \%$ by 2019 see [4].

The motivation behind the participation of foreign investors in emerging markets is portfolio risk reduction that is gained through global diversification. Nevertheless, this reduction can be achieved as long as the correlation between countries is low [7].

"Stock returns are expected to be theoretically related to foreign investor transactions. This is not surprising since foreign investor participation contributes to risk diversification and stock market liquidity. A consistently base-broadening hypothesis also asserts that foreign investor participation improves risk-sharing and liquidity, which cause the required risk premium to decrease and stock prices to increase in turn" (AVCI, 2015, p. 32) [8].

\subsection{The Problem Statement}

\section{The objective of the study}

This study aims to examine the expected causal relationships between buying of foreign investors, selling of foreign investors and stock market index performance in the Saudi stock market.

\section{Research Questions}

The search problem is determined by the following questions:

1) Are foreign investors' trade causes a change in stock market index return in Saudi Arabia?

2) Is the TASI index return cause a change in buying or selling behavior of

${ }^{1}$ Indirect foreign investment by swap agreements started in 2008. Direct foreign investment in 2015. 
foreign investors?

\subsection{The Scope of the Study.}

- The objective limit: the liberalization of the stock market: the impact of foreign investors buying and selling on the performance of the Saudi stock market TASI.

- Spatial limit: Saudi stock market TASI.

\subsection{The Relevance of the Study}

This study is the first of its kind-to the knowledge of the researcher-which explains the capital market liberalization and the impact of foreign investors buying and selling in the performance of the Saudi stock market index TASI.

This study is useful to the Capital Market Authority to evolve new plans to develop the Saudi market by working on other mechanisms after the liberalization of the market to attract new capital and transfer knowledge and experience to local financial institutions and investors and raise the efficiency of the market.

The study also will enable the Ministry of Commerce and Investment and Saudi Arabian Monetary Agency to make optimal use of foreign entities as institutions or investment assets for the benefit of the investment sector in general and citizens (investors, employees, and customers) in particular.

\section{Review of Literature}

The study by Chan and Kwok [9] (2016) examines reforms of the stock market to observe and permit the subdivision of the Shanghai Stock Exchange's stocks for speculation by foreign investors. According to the predicted stats their theory, price reappraisal of investible stocks makes a directly proportional link with the reduction of systematic risk. This implication is examined by the use of 856 stock's sample in the Shanghai market, through which this study explores that in the duration of eight-month window among implementation and reform announcement, risk-sharing elucidates only one-fourth of the revaluation of the price of investible stocks. The evidence and information engendered by the modification and reform are more accurately priced into stocks having developed degree of market liquescent, information transparency, and global exposure and informed trading.

Study of Grosse and Trevino [10] (1996) explores contributing factors relevant to the elucidation of FDI in the United States by the investment and theoretical origin of the country. Information stats elucidates that exports of the country are more influential and significant to the market size of the home country and the United States. Significantly adverse impacts contain the exports of the home country from the United States, ethnic and geographic detachments of the home country from the United States, and the exchange rate ( $\mathrm{f} x / \$)$.

The research study of Onyuma [11] (2009) examines the intensity of the existence of daily and monthly seasonal anomalies in Kenya's stock market. Data on 
charges and accustomed revenues derivative from the NSE 20 index were evaluated using deterioration analysis to classify the conduct of stock investors in Kenya from 1980 to 2006. Results of this evaluation reveal Monday existing on the lowest rank when it comes to the negative returns, while on the other hand Friday and January on the whole yield the highest positive returns. These results are beneficial in terms of getting indications of eccentricity from the theory of efficient markets and for illustrating concluding assumptions regarding anomalies in an evolving stock market. Economic news announcement unconfined on Thursday and Friday leads to the indication of the highest and lowest return instability on Friday and Monday respectively. The behavior of the investors of the foreign portfolio and postponements in receiving news exposed by foreign financial markets influence the returns and revenues on a greater level. By organizing and establishing trading strategies, investors become able to get regular benefits, and Day of the week and patterns of January add more in the volatility and returns to facilitate investors.

Structural deviations in Doha Securities Market (DSM) are studied by Abdullah and Ghassan [12], by using GARCH models through the time of 2002-2008. This matter is linked to the level of liberation given to foreign investors for being a part of the market in 2005. Through analysis return equation's high risk is revealed. The drift of information provided to the market derives from the return variable's risk is indicated by the GARCH-Mean model. There exists a steady movement in the index volatility, however, it was not so much in the first sub-period as compared with the persistence after the access of foreign investors.

Paper of Sevil et al. [13] (2012) inspects that whether investors from foreign regions conduct their decisions regarding portfolio investment on the evidence of ISE market index return or not, it also observes that either their conduct is centered on unpremeditated effect on transition in Istanbul Stock Exchange index return or not. After the analysis of time series variables, results of causality analysis makes it evident that there is a Vector Error Correction Granger Causality as a consequence of buying of foreign investors to the index of market returns. Period analysis discloses that increasing market returns originated from the buying of foreign investors can produce new purchases. Most significant of all the results is the finding that return of the stock market does not cause Granger to do buying or selling of foreign investors. Noise trading by foreign investors may indicate that cause to buy and sell securities may up shoot from sentiments and expectations.

Rhee and Wang [14] (2009) deliver firsthand information on the liquidity influence of foreign investment in rising stock markets. They utilized in their study, ownership by foreign individual stock sources as an undeviating measurement of foreign existence in the domestic market to analyze and observe the relation among liquidity and foreign presence. Their paper studies the causality among the liquidity and foreign institution's ownership while monitoring for perseverance in measure of liquidity and foreign ownership. It also designated 
that foreign holdings carry a destructive influence on future liquidity: a $10 \%$ enhancement in the possession of foreign institution in the running month is interrelated with the proximity of $2 \%$ upsurge in the prevalence of the bid-ask, $3 \%$ tumbling in-depth, and $4 \%$ rise in the coming month for price sensitivity. It stimulates the opinion that foreign institutions increase liquidity in trivial rising markets. The outcomes are steady with the impacts of negative liquidity of the ownership of institutional investor in developed markets.

Determinants of the confidence of investors for firms enumerated at Nairobi Stock Exchange (NSE) are investigated by Bitok et al. [15] (2011) for the period from 2001 to 2008. Informative statistics on the impulsiveness of the stock market was gathered based on macroeconomic elements and news and at NSE. These events and news are influential enough for the stock market as portrayed by the variations in the prices as investor sentiment's measure that is quite much able of elaborating a specific intensity of the variations in the index of the stock market. Consequences of this whole scenario specify that the stability at the political and economic level, economic growth, and liquidity of stock market play a vital contribution to the development of the stock market. Here the research concludes that movements regarding daily price in the NSE are strongly relevant to the sentiments of investors. As a result, the potential elucidation for stock price movements relies on the psychology of investors. It presents liquidity in the stock market and economic growth as significant determinants for the growth of the stock market.

Froot et al. [16] (2001) in their paper reveals the conduct of flows of the international portfolio into and out of 46 countries in the time from 1994 to 1998. Data collected from state street bank and trust, encompass above 3 million trades by the institution of the customer. First of all, it detects the regional elements within the flows. Secondly, the flows are highly incessant-as the diligence decays steadily over time. Thirdly, flows are immensely influenced by past returns, so that investor trend following is explicit. Fourthly Froot et al.'s (2001) paper explore that inflows contain forecasting strength for future evolving market returns, but not for the returns of the developed country. Fifthly, it covers the local stock prices' sensitivity, inflows to be optimistic and regulate the influences of future revenues negatively. Finally, it explores and denies that the confident covariance of profits and inflows is associated with the statistics drawback on the fragment of international investors.

Inoue's [17] (2008) paper observes the connections in terms and apart from stock returns and Foreign Institutional Investment (FII) in India. Paper further implies the Cheung and Ng's [18] (1996) approach of Cross-Correlation Function and utilizes daily data for the January 1999 to March 2008's timeframe divided into two periods before and after May 2003. Its empirical results revealed that there exist uni-directional causalities in relevance and difference from stock returns of FII flows, not relevant to the sample period, while on the other hand reverse causalities originated in the period initiating with 2003. Overall results 
refer to the FII flows containing and influence on the Indian stock prices' movement during the latest period.

Research work of Bekaert and Harvey [19] (2000) evaluate the consequences of liberalizations in the market in the rising impartial markets on the capital cost using cross-sectional time-series model. This liberalization is characterized by regulatory changes, country funds, and depositary receipts' introduction and breaks in emerging markets and equity capital flow. Their research manages for other economic events that can portray the influence of foreign entrepreneurs on local markets. Across many provisions, the cost of capital always drops after the liberalization of the capital market with the outcome varying between 5 and 75 basis points.

Karolyi [20] (2002) identifies that either the influence of market crisis is intensified by the activity of overall portfolio investment for foreign investors in Japan or not, or to what extent it can reflect positive-feedback trading conduct. The statistics lure from weekly reports to the Tokyo Stock Exchange (TSE), cumulative purchases and sales of Japanese equities by foreigners and local institutional and individual investors. This paper identifies evidence of constant positive-feedback trading beforehand, for the duration of the process and after the Asian catastrophe among foreign investors, while banks of Japan, financial institutions, trust and companies with investment themselves were antagonistic contrarian investors. No indication reveals the trading of the activity by foreigners damaged the markets during the crisis.

Kim and Wei [21] (2002) examine the Korean investor's portfolio during and before the crisis. During the currency crisis, similarities and difference in trading are highlighted. Initially, non-resident investors are the one with positive feedback while on the other hand resident investors occupies the negative feedback to make a contradicted relation, but later on during the crisis, they also shifted to the category of investors with positive feedback. It also reveals that unlike institutional investors, individual investors make herd more pointedly. Changing scenario of Korean and Western news coverage are interlinked with the transformation in overall selling by non-resident investors comparative to resident investors.

Foreign ownership is characterized by Dahlquist and Robertsson [22] (2001) in their paper using the dataset of ownership and Swedish firm's attributes. They analyzed that foreign investors most probably prefer large firms because of their low payment and extras and position with large cash on their balance sheet. Additionally, on the preference of large firms this research considers that market liquidity and existence in international markets can be measured and analyzed by the terms of export sales or listing on other exchanges, it looks as if it can examine foreign holdings more influentially then those firms that size alone. Firms with dominant owners are attempted to underfeed by foreigners. Most significantly, this research definites that most of the rip-offs associated with foreign ownership are compelled by the fact that foreign investors usually are other 
institutional investors or mutual funds. This paper also explores the biased conduct of institutional investors, unlike foreign investors. Finally, utilizing ownership data on a country level, this paper discovers that the results are predominantly substantial among U.S. investors, who are known as the largest institutions among foreign investors.

Kang and Stulz [23] (1997) test the determinants of the home bias in holdings of the portfolio by using data of foreign stock ownership in Japan from 1975-1991. It is indicated by designing different evidence in this research that the existing models of choice of the international portfolio that international investors hold are national market's portfolios or the one with the qualities with highly expected return stock. This research retains the idea that the foreign investors cumbersome firm's shares in establishing industries, large firms, firms with less unsystematic risk, firms with high accounting performance, and firms with low influence. Through evidence, it becomes obvious that great foreign ownership is occupied by small companies with more export power. After monitoring the company's size, there is found no evidence that foreign ownership is associated to have predictable returns of shares. This research reveals that a model with size-based data statistics and deadweight costs can harvest asset allocations with evidence.

Choe et al. [24] (1999) in their research work elaborate on the influence of foreign investors on stock returns in Korea from November 30, 1996, to the end of 1997 utilizing trade and data order. They explore positive feedback's strong evidence trading and droving by foreign investors before the era of Korea's economic devastation. Herding retreats and feedback regarding positive trading by foreign investors often disappears during the crisis. No evidence is found in research to prove that trades by foreign investors had an undermining upshot on Korea's stock market over our sample period. Significantly the market quickly attuned to big sales by foreign investors, and also negative abnormal returns do not follow these sales (Elsevier, 1999).

Influence of foreign institutional investors on the steadiness of Chinese stock markets is investigated by Schuppli and Bohl [25] (2010) in their research paper. Prior literature visions that investor group has deteriorated the feedback traders. This paper practices the eradication of ownership restrictions on A-shares as a regular experiment. There is momentous evidence that foreign organizations have an unchanging influence on Chinese stock markets and subsidize to market with great proficiency. This finding is vigorous across interactions, sample periods, size quintiles and substitute model stipulations. In another side, domestic stockholders seem to participate in positive feedback trading. Our results have imperative allegations for the market parameter.

Errunza's [26] paper (2001) examines the reforms of the local market and the relaxation of capital control to fascinate foreign portfolio investment (FOIs), as it is being an important element of development strategy. The immediacy of market openings and sudden and extensive swings in international capital flows 
contributed credibility to the conception that the liberalization was the chief perpetrator in for participating in the topical Asian crisis. Henceforth this research reconsiders the FPIs' costs and benefits from the perception of the beneficiaries. It significantly investigates the disparities of the contributions of FPI and recommends empirical stats regarding the union among market development and FPIs, capital market integration's degree, capital cost, and correlation and market volatility of correlation. Payback of FPIs with evidence looks strong, while the policy concerns for mobilization of resources, co-movements in the market, contamination, and precariousness are highly unwarranted. Bu this researcher forms few policy commendations regarding prerequisites for the openings capital market, market regulation, and liberalization sequencing.

Affected countries and three financial crises in different eras and exchange rate are explored by Lipsey [27] (2001) as it wrought in various forms apart from the forms of investment. Countries got affected due to direct investment inflows during exchange rate crises in Latin America, Mexico, and East Asia in 1982, 1994 and 1997 respectively. Countries' crises due to direct investment have been significantly alleviated than portfolio's inflows or any else investment form. Manufacturing affiliates of Unites States have transferred their sales from hosting countries to the markets exporting to a great extent with vitally different yet higher period than other host country's firms. They swapped from their markets partially by more abruptly curtailing their local sales, specifically in footings of U.S. dollar values. In those cases, where research contains the data, U.S. associates have also inclined to endure capital expenditure rate during crises.

David et al. [28] (2006) paper elucidate the influence of foreign ownership on investments strategies in various firms of Japan. Two contradicting views are being investigated by prior researches on such investors, first one is that their determined trading indicates the pressure for comparatively shorter returns that increase underinvestment and the second one is that their dynamic trading reaches towards appropriate investments. Research here studied the affiliation amongst strategic investments and foreign proprietorship analyzes vibrant data of a sample of 146 manufacturing firms of Japan for the period from 1991 to 1997. It is explored here that foreign ownership nurtures the strategies of investments to a vital extent, as with the growing opportunities of firms, results are more appropriate, unlike the situation where opportunities are not so high. Their research sums up that foreigner's ownership leads to appropriate investment.

Kim et al. [29] (2010) discuss their focus by two-dimensional aims and concerns. Theirs first finding is to expose the objective that either the meager corporate governance influences foreign investors' participation or not. The second objective here is to analyze the efforts of firm-level for improved corporate governance for foreign investments. Revised results discover that extraneous impartial ownership is damagingly allied with ownership attentiveness of firms, but it is positively linked with efforts of firms for improved corporate governance. Additionally, finding out that foreign investors occupy different patterns of conducts from their domestic equivalents, reveals less sensitivity towards corpo- 
rate governance than the. In addition to finds that foreign investors show different behavioral patterns from their domestic counterparts, as the latter group shows less sensitivity to the corporate governance issue than the prior group.

Probability for having an edge by domestic investors over foreign investors is discussed by Choe et al. [30] (2005) in their research work. That edge is usually tested by Korean data, and its findings reveal that managers for foreign money pay more, unlike domestic money's managers, while buying and receiving less when selling for large and medium trades. Sample for the measurements of dilly trade-weighted here comprises 21 foundational points for purchases and 16 for sales. While finding out that individual domestic investors having an edge on foreign investors it is indicated that unlike domestic investors. Prices work more against foreign investors.

\section{Methodology and Data}

\subsection{Type of Study}

The experimental research goal is to give conclusions about the causal relationships through the variables in the hypothesis of the research. In these researches types, the variables that are being studied are known as the independent variable and the dependent variable. The independent variable that been tested is the causing variable that the experimenter was manipulated by. The dependent variable in an experiment is a deliberate variable that is required to be impacted by the experimental control. The hypothesis of the research recommends that the created independent variable will cause changes in the dependent variables that were measured.

To achieve the objective of the study, the Granger causality method was used to investigate whether there is a causal relationship between buying of foreign investors, selling of foreign investors and stock index performance. The study was based on the quantitative method using time series [31] [32], by using Eviews 9.0 and Excel, the study used the monthly data from 2008-2018.

\subsection{Research Model}

In order to determine the causal relationships between foreign investors buy, sell and Index, the Granger ${ }^{2}$ causality Sevil et al. $(2006)^{3}$ test was used. Granger equations are determined as follows:

$$
\begin{aligned}
\Delta X_{t} & =\alpha_{X}+\sum_{i=1}^{m} \beta_{X, i} \Delta X_{t-i}+\sum_{i=1}^{m} \gamma_{X, i} \Delta Y_{t-i}+u_{X, t} \\
\Delta Y_{t} & =\alpha_{Y}+\sum_{i=1}^{m} \beta_{Y, i} \Delta Y_{t-i}+\sum_{i=1}^{m} \gamma_{Y, i} \Delta X_{t-i}+u_{Y, t}
\end{aligned}
$$

\section{Dependent variable:}

$Y=$ Tadawul All Share Index (INDEX).

\section{Independent variables:}

${ }^{2}$ Clive William John Granger is a British econometrician known for his contributions to non-linear time series.

${ }^{3}$ Sevil, G. Özer, M. and Kulalı, G. (2012). Foreign Investors and Noise Trade in Istanbul Stock Exchange. Borsa Istanbul Review. Vol.14, Issue 4, December 2014, pp 236-241. 
$X_{1}=$ Foreign investor (BUY) $X_{2}=$ Foreign investor (SELL)

$u$ is the error term and $b$ 's are model coefficients to be fitted. The null hypothesis of the test for Equation (1) is H0: $\sum_{i=1}^{m} \gamma_{X, i}=0$. For Equation (2), H0: $\sum_{i=1}^{m} \gamma_{Y, i}=0$. If the predicted $F$ value is greater than the Table Critical $F$ value; in Equation (1), $Y$ means $X$ in Granger while causing; in Equation (2), $X$ causes $Y$ to Granger.

\subsubsection{Stationary in the Time Series}

\section{1) ZAUroot Test with Structural Breaks}

Before conducting the Granger causality test, we need to know the properties of the time series for each variable, by investigating the stationarity of the variables, by using $\mathrm{Z} \& \mathrm{~A}$ (1992) unit root test with structural breaks [33]. $\mathrm{H}^{\circ}$ is a unit root process without any exogenous structural breaks, and $\mathrm{H} 1$ is a trend-stationary process with possible structural change occurring at an unknown point in time. Research suggests three different test equations ( $A, B$ and C). They are:

$$
\begin{gathered}
y_{t}=\wedge \mu^{A}+{ }^{\wedge} 0^{A} D U_{t}\left(\lambda^{\wedge}\right)+\wedge \beta^{A} t+\wedge \alpha^{A} y_{t-1}+\sum_{j=1}^{k} c^{\wedge}{ }_{j} \Delta y_{t-j}+\wedge e_{t} \\
y_{t}=\wedge \mu^{B}+\wedge \beta^{B} t+\wedge \gamma^{B} D T_{t}^{*}\left(\lambda^{\wedge}\right)+\wedge \alpha^{B} y_{t-1}+\sum_{j=1}^{k}{ }^{\wedge} c^{B}{ }_{j} \Delta y_{t-j}+{ }^{\wedge} e_{t} \\
y_{t}={ }^{\wedge} \mu^{C}+{ }^{\wedge} 0^{C} D U_{t}(\wedge \lambda)+\wedge \beta^{c} t+\wedge \gamma^{c} D T_{t}^{*}\left(\lambda^{\wedge}\right) \\
+{ }^{\wedge} \alpha^{c} y_{t-1}+\sum_{j=1}^{k}{ }^{\wedge} c^{c} \Delta y_{t-j}+\wedge e_{t}
\end{gathered}
$$

where $D U_{t}$ denotes the dummy variable for the change in level $\left(D U_{t}(\lambda)=1\right.$ if $t>$ $T_{\lambda}$, or 0 otherwise), $D T_{t}$ denotes the dummy variable for the change in trend $\left(D T_{t}(\lambda)=T_{t}\right.$ if $t>T_{\lambda}$, or 0 otherwise), $D T_{t}$ is the so-called crash dummy supposed to capture a possible and sudden shift in the series $D T_{t}=1$ if $t=T+1$, or 0 otherwise).

\section{2) ADF Unit-root Test with Structural Breaks}

Perron uses a modified Dickey-Fuller (DF) unit root tests that contain dummy variables to account for one known, or exogenous structural break. The breakpoint of the trend function is fixed (exogenous) and chosen autonomously of the data. Perron's (1989) unit root tests allow for a break under each of the null and alternative hypothesis. These tests have less power than the standard Dickey-Fuller type test when there is no break. In case of structural break ADF bias towards non-rejection of a unit root. Based on Perron (1989), the following three equations are estimated to test for the unit root. The equations take into account the existence of three kinds of structural breaks: a "crash" model (6) which allows for a break in the level (or intercept) of series; a "changing growth" model (7), which allows for a break in the slope (or the rate of growth); and lastly one that allows both effects to occur simultaneously, i.e. one time change in both the level and the slope of the series (8).

$$
x_{t}=\alpha_{0}+\alpha_{t} D U_{t}+d(D T B)_{t}+\beta_{t}+\rho x_{t-1}+\sum_{i=1}^{p} \varnothing_{i} \Delta x_{t-1}+e_{t}
$$




$$
\begin{gathered}
x_{t}=\alpha_{0}+\gamma D T_{t}^{*}+\beta_{t}+\rho x_{t-1}+\sum_{i=1}^{p} \varnothing_{i} \Delta x_{t-1}+e_{t} \\
x_{t}=\alpha_{0}+\alpha_{t} D U_{t}+d(D T B)_{t}+\gamma D T_{t}^{*}+\beta_{t}+\rho x_{t-1}+\sum_{i=1}^{p} \varnothing_{i} \Delta x_{t-1}+e_{t}
\end{gathered}
$$

where $D U_{t}$ (the intercept dummy) represents a change in the level; $D U_{t}=1$ if $\left(t>T B\right.$ ) and zero otherwise; $D T_{t}$ (the slope dummy), also $D T_{t}^{*}$ represents a change in the slope of the trend function; $D T^{*}=t-T B \quad\left(\right.$ or $D T_{t}^{*}=t$ if $t>T B$ ) and zero otherwise; the crash dummy $(D T B)=1$ if $t=T B+1$, and zero otherwise; and $T B$ is the break date. All of the three models have a unit root with a break under $\mathrm{H}^{0}$, as the dummy variables are inserted in the regression under $\mathrm{H}^{\circ}$. Whither $\mathrm{H}_{1}$ is a broken trend stationary process.

\subsubsection{Johansen Co-Integration Test}

The first differences of the three variables used in the study after determining that they are. The possible co-integration between these three variables comes to test their relationship, Cointegration relationships between variables. In order to investigate, the Johansen co-integration test was preferred. The first differences of cointegrated I (1) variables structure the VECM, their lags, and some error correction terms. The Johansen test is used to test the relationships between 1 (1) stationary variables using the following VECM model.

$$
D y_{t}=\mu+\Pi y_{t-1}+\sum_{i=1}^{P} \Gamma_{i}^{*} D y_{t-k}+\varepsilon_{t}
$$

\subsubsection{VEC Granger Causality Test}

To investigate the causal relationship between buying of foreign investors, selling of foreign investors and stock index performance in any direction. Researcher suggests Granger causality methodology be used.

\subsection{Hypotheses and Conceptual Framework}

The following hypothesis is formed:

- Hypothesis 1: Foreign investors BUY Granger-causes INDEX.

- Hypothesis 2: Foreign investors SELL Granger-causes INDEX.

- Hypothesis 3: INDEX Granger-causes Foreign investors BUY.

- Hypothesis 4: INDEX Granger-causes Foreign investors SELL.

Figure 1 summarizes the hypotheses within the conceptual framework of this study. The direction of the arrow indicates the direction of causality from a variable to the other.

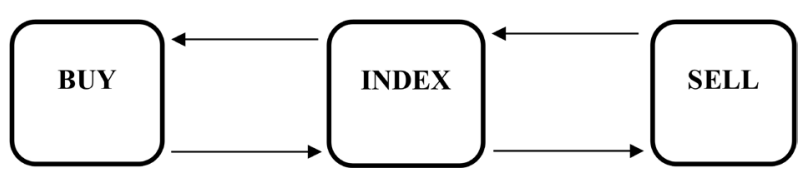

Figure 1. Conceptual framework for this research.

\subsection{Data Collection Method}

The data used are secondary (Historical Market Data) extracted from Monthly Stock Market Ownership and Trading Activity Report "trading by nationality" 
from (TADAWUL ${ }^{4}$ ) represented as foreign transactions BUY \& SELL. Tadawul All Share Index (TASI) Extracted from INVESTING ${ }^{5}$ as monthly prices from 2008 to 2018.

\subsection{Population and Study Sample}

The study sample consists of monthly data for foreign buy, sell and TASI index in Saudi stock market from 2008 Jan until 2018 Dec. The research used different types of foreign traders which include: GCC individuals, GCC Institutions, Arabs (NON-GCC) residents, Foreigners (Residents), Foreigners (Swap Agreement) Foreigners (QFI) and Foreign DPMs, Table 1 explain the descriptive statistic for these types:

Table 1 represents the descriptive statistics for types of investors. The mean value of buying of GCC Citizens, Institutions and Arabs investors is 2.75 billion SR while the mean of selling is 2.71 billion SR. The mean value of buying of Foreigners (Residents), Swap Agreement, QFI, Strategic partners and Foreign DPMs investors is 2.54 billion SR while the mean of selling is 2.55 billion SR.

\section{Results and Interpretation of Results}

\subsection{Descriptive Statistics and Correlation}

The research used monthly data. The time period is 2008:1 and 2018:12 $(\mathrm{t}=$ 132). Table 2 represented descriptive statistics related to variables.

Table 1. Descriptive statistics for types of investors.

\begin{tabular}{cccccc}
\hline & \multicolumn{2}{c}{ GCC Citizens, Institutions and Arabs } & \multicolumn{2}{c}{ Foreigners (Residents), Swap Agreement, QFI, Strategic partners } \\
and Foreign DPMs
\end{tabular}

${ }^{4}$ https://www.tadawul.com.sa/wps/portal/tadawul/markets/reports-\%26-publications/periodical-pub lications

${ }^{5}$ https://www.investing.com/indices/tasi-historical-data 
Table 2. Descriptive statistics for variables at level values.

\begin{tabular}{cccc}
\hline & $B U Y$ & $S E L L$ & INDEX \\
\hline Mean & $5,267,909,050$ & $5,276,225,350$ & 7324.460455 \\
Standard Error & $176,164,432.1$ & $172,389,178.2$ & 117.9966438 \\
Median & $4,953,921,116$ & $4,890,335,557$ & 7028.51 \\
Mode & $2,562,315,530$ & $3,218,771,140$ & $\# \mathrm{~N} / \mathrm{A}$ \\
Standard Deviation & $2,023,975,233$ & $1,980,600,868$ & 1355.678225 \\
Sample Variance & $4.09648 \mathrm{E}+18$ & $3.92278 \mathrm{E}+18$ & $1,837,863.449$ \\
Kurtosis & 0.906833704 & 2.750270687 & -0.022908273 \\
Skewness & 0.921172281 & 1.240356344 & 0.557525452 \\
Range & $11,052,485,202$ & $12,148,080,487$ & 6727.53 \\
Minimum & $1,212,203,825$ & $2,310,526,293$ & 4384.59 \\
Maximum & $12,264,689,027$ & $14,458,606,779$ & $11,112.12$ \\
Sum & $6.95364 \mathrm{E}+11$ & $6.96462 \mathrm{E}+11$ & $966,828.78$ \\
Count & 132 & 132 & 132 \\
\hline
\end{tabular}

Table 3. Correlation for variables at level values.

\begin{tabular}{cccc}
\hline & BUY & SELL & INDEX \\
\hline BUY & 1 & 0.75501151 & 0.605552978 \\
SELL & 0.75501151 & 1 & 0.534553271 \\
INDEX & 0.605552978 & 0.534553271 & 1 \\
\hline
\end{tabular}

Correlations of the variables are represented in Table 3.

The mean value of foreign investors buying is 5.26 billion SR while the mean of foreign investors selling is 5.27 billion SR. The maximum value of foreign investors buy is 12.2 billion SR while the maximum of sell is 14.4 billion SR, while a minimum of buying of foreign investors 1.21 billion SR and for selling is 2.31 SR in the analysis period. The mean value of TASI index is $7324.46 \mathrm{SR}$ while the maximum is $11,112.12 \mathrm{SR}$ and the minimum $4384.59 \mathrm{SR}$.

The correlation between Index and buying of foreign investors is 0.60 , which indicate a moderate positive correlation between buy and index. While the correlation between Index and the selling of foreign investors is 0.53 , that illustrates the moderate positive correlation between sell and index. The correlation between foreign investors buying and selling is 0.75 , which is indicating the high positive correlation between buying and selling. The higher the coefficient is the stronger the correlation and the better the predictive or explanatory power.

\subsection{Unit Root Tests with Structural Breakpoint}

\subsubsection{Zivot and Andrews Unit Root Test}

Table 4 illustrates Zivot and Andrews Unit-root [34] Test Result. For INDEX, the 
Table 4. Zivot and Andrews unit-root test result.

\begin{tabular}{cccccccccc}
\hline \multirow{2}{*}{ Model } & \multicolumn{3}{c}{ INDEX } & \multicolumn{3}{c}{ BUY } & \multicolumn{3}{c}{ SELL } \\
\cline { 2 - 10 } & A & B & C & A & B & C & A & B & C \\
\hline Break point & $2015 \mathrm{M} 08$ & $2014 \mathrm{M} 06$ & $2015 \mathrm{M} 08$ & $2015 \mathrm{M} 05$ & $2014 \mathrm{M} 12$ & $2015 \mathrm{M} 05$ & $2015 \mathrm{M} 06$ & $2014 \mathrm{M} 12$ & $2014 \mathrm{M} 01$ \\
ZA test statistic & $-4.864802^{\mathrm{a}}$ & -3.808255 & $-4.844847^{\mathrm{a}}$ & $-5.451233^{\mathrm{c}}$ & $-5.019624^{\mathrm{c}}$ & $-5.421114^{\mathrm{b}}$ & $-5.788624^{\mathrm{c}}$ & $-5.416380^{\mathrm{c}}$ & $-5.914394^{\mathrm{c}}$ \\
K & 1 & 1 & 1 & 9 & 9 & 12 & 9 & 9 & 12 \\
Critical values & & & & & & & & & \\
$1 \%$ & -5.34 & -4.80 & -5.57 & -5.34 & -4.80 & -5.57 & -5.34 & -4.80 & -5.57 \\
$5 \%$ & -4.93 & -4.42 & -5.08 & -4.93 & -4.42 & -5.08 & -4.93 & -4.42 & -5.08 \\
$10 \%$ & -4.58 & -4.11 & -4.82 & -4.58 & -4.11 & -4.82 & -4.58 & -4.11 & -4.82 \\
\hline
\end{tabular}

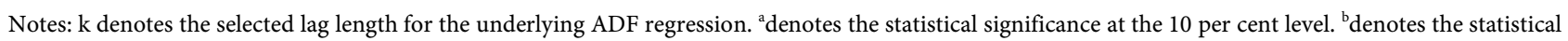
significance at the 5 per cent level. ${ }^{c}$ denotes the statistical significance at the 1 per cent level.

unit-root null hypothesis with a structural break in the intercept (model A) is rejected at the 10 per cent level. Similarly, in both the intercept and the trend (model C) is rejected at the 10 per cent level.

For BUY, all three tests indicate some evidence against the unit-root null hypothesis, especially using model A and B which may interpret The Tadawul All Share Index (TASI) dropping dramatically since mid-2015, Whilst the decline in oil prices has been an obvious factor in this decline, a number of other developments have played their part in dampening investor sentiment.

Finally, for SELL all three tests indicate some evidence against the unit-root null hypothesis, which may interpret the corresponding decline in Index (TASI). From this table, it can be said that the effects of oil prices decline on the variables started with index return in June 2014. From that, it can be said that all three variables are trend stationary.

\subsubsection{Augmented Dickey-Fuller Unit Root Test}

Table 5 presents the Augmented-Dicky Fuller unit-root test results. According to Table 5, the three variables are not stationary in level (have a unit root), but after taking the first difference they become stationary. The null hypothesis of the series has unit root for $\mathrm{ADF}$ is rejected.

\subsection{Cointegration Test}

Lag length selection result is explained in Table 6. The likelihood ratio test suggested 7 lags for a vector autoregressive model chosen by LR, so a practical step is to use p-1 lags for VECM and Johansen co-integration. In this case, we used 6 lags for the Johansen co-integration approach, which the Johansen Co-integration test result illustrated in Table 7, it suggested the existence of at least 2 cointegrating relationships in the dataset indicating that we should estimate VECM rather than unrestricted Vector Auto regression model. It can be said that the three variables have long run associations, i.e. they move together in the long run. 


\subsection{VEC Granger Causality Test}

Based on the VEC Granger causality test that explained in Table 8, it can be said

Table 5. Augmented-Dicky fuller unit-root test result.

\begin{tabular}{|c|c|c|c|c|c|c|c|c|c|}
\hline \multirow{2}{*}{ Breaking } & \multicolumn{3}{|c|}{ INDEX } & \multicolumn{3}{|c|}{ BUY } & \multicolumn{3}{|c|}{ SELL } \\
\hline & \multicolumn{9}{|c|}{ level } \\
\hline Prob & 0.0533 & 0.1185 & 0.2239 & 0.5411 & 0.7363 & 0.9124 & 0.4767 & 0.6354 & 0.9427 \\
\hline T-statistic & -4.838233 & -4.820587 & -3.874002 & -3.736254 & -3.653435 & -2.511392 & -3.837198 & -3.823924 & -2.395790 \\
\hline $1 \%$ level & -5.347598 & -5.719131 & -5.067425 & -5.347598 & -5.719131 & -5.067425 & -5.347598 & -5.719131 & -5.067425 \\
\hline $5 \%$ level & -4.859812 & -5.175710 & -4.524826 & -4.859812 & -5.175710 & -4.524826 & -4.859812 & -5.175710 & -4.524826 \\
\hline \multirow[t]{2}{*}{$10 \%$ level } & -4.607324 & -4.893950 & -4.261048 & -4.607324 & -4.893950 & -4.261048 & -4.607324 & -4.893950 & -4.261048 \\
\hline & \multicolumn{9}{|c|}{ First difference } \\
\hline Prob & 0.01 & 0.01 & 0.01 & 0.01 & 0.01 & 0.0493 & 0.01 & 0.01 & 0.0676 \\
\hline T-statistic & -9.516945 & -9.859687 & -9.827242 & -7.365212 & -7.265058 & -4.531111 & -7.204356 & -7.422389 & -4.418601 \\
\hline $1 \%$ level & -5.347598 & -5.719131 & -5.067425 & -5.347598 & -5.719131 & -5.067425 & -5.347598 & -5.719131 & -5.067425 \\
\hline $5 \%$ level & -4.859812 & -5.175710 & -4.524826 & -4.859812 & -5.175710 & -4.524826 & -4.859812 & -5.175710 & -4.524826 \\
\hline $10 \%$ level & -4.607324 & -4.893950 & -4.261048 & -4.607324 & -4.893950 & -4.261048 & -4.607324 & -4.893950 & -4.261048 \\
\hline
\end{tabular}

Table 6. Lag length selection result.

\begin{tabular}{ccccccc}
\hline Lag & LogL & LR & FPE & AIC & SC & HQ \\
\hline 7 & -6217.551 & $17.13527^{\star}$ & $6.16 \mathrm{e}+41$ & 104.7259 & 106.2590 & 105.3485 \\
\hline
\end{tabular}

Table 7. Johansen co-integration test result.

\begin{tabular}{ccccc}
\hline $\begin{array}{c}\text { Hypothesized } \\
\text { No. of CE(s) }\end{array}$ & $\begin{array}{c}\text { Trace } \\
\text { Statistic }\end{array}$ & Prob. & $\begin{array}{c}\text { Max-Eigen } \\
\text { Statistic }\end{array}$ & Prob. $^{* *}$ \\
\hline None $^{*}$ & 90.34210 & 0.0000 & 64.07898 & 0.0000 \\
At most $1^{*}$ & 26.26312 & 0.0066 & 21.41364 & 0.0061 \\
At most 2 & 4.849485 & 0.3003 & 4.849485 & 0.3003 \\
\hline
\end{tabular}

*denotes rejection of the hypothesis at the 0.05 level; ${ }^{* *}$ MacKinnon-Haug-Michelis (1999) p-values.

Table 8 . VEC granger causality test result.

\begin{tabular}{ccc}
\hline Null Hypothesis & Chi-sq & Prob. \\
\hline BUY does not Granger Cause INDEX & 17.00403 & 0.0093 \\
SELL does not Granger Cause INDEX & 17.05751 & 0.0091 \\
INDEX does not Granger Cause BUY & 6.811434 & 0.3386 \\
SELL does not Granger Cause BUY & 19.69998 & 0.0031 \\
INDEX does not Granger Cause SELL & 6.548816 & 0.3646 \\
BUY does not Granger Cause SELL & 2.265178 & 0.8938 \\
\hline
\end{tabular}


that:

- Foreign investors BUY Granger-causes INDEX.

- Foreign investors SELL Granger-causes INDEX.

The results of VEC Granger causality illustrate the importance of foreign investors BUY and SELL to explain stock market movements.

\section{Summary and Conclusions}

This study aims to determine if a cause exists between foreign investors buy and sell and the Saudi stock market performance. This research applies the granger causality to study the relationship between foreign investors buying, selling and the Saudi stock market performance for the period of Jan. 2008 to Dec. 2018. The conclusion of this study illustrates the movement of the foreign investors buy and sells and their impact on the Saudi stock market performance, in addition to indicating that foreign investors make their transaction decisions according to performance index information. Since the interaction of variables is different in emerging markets, developed markets, and frontier markets, several countries ranging from the United States and China to Kenya have been reviewed as part of literature review before proceeding with statistical testing of data related to Tadawul. In almost all the global markets, the foreign buy and sell are significantly influencing the economy that is in, and the movements in these variables do affect the stock market performance. Based on the interpretation of results, Unit root tests confirmed that all variables are stationary in their first difference based on ADF test with structural breaks and Zivot Andrew unit root test. Based on ADF, all variables are stationary in their first difference. ZAUroot indicates that for INDEX, the unit-root null hypothesis with a structural break in the intercept is rejected at the 10 per cent level. Other variables are stationary in their first difference. Johansen co-integration approach suggested the existence of at least 2 cointegrating relationships in the dataset. It can be said that the three variables move together in the long run. Finally, VEC Granger causality results on the importance of foreign investors BUY and SELL to explain stock market movements.

This conclusion is particularly important for Saudi stock market performance. Furthermore, policymakers represented as CMA can use these findings to make policies boosting the stock performance. For example, foreign investor's ownership and their regulations can be reviewed and corrected, guard against manipulation of stock prices and misuse of their ownership in contravention of the ethics and laws of the capital market.

Discoveries likewise demonstrate the delicacy of the Saudi securities exchange to monetary issues of outside nations which will be reflected on the foreign traded capitals. The indicated affectability of TASI must be decreased by pulling in more local investors into the market. With this point, initial step could be a determination of the purposes behind the low participation of domestic investors in TASI. One explanation behind that is the lack of reserved funds. First, 
government ought to execute solutions and programs that aim to raise the citizen awareness about saving so as to rise the saving percentage of domestic investors. One of the objectives of the Financial Sector Development Program includes enhancement and empowerment of financial planning (retirement, savings, etc.) see [8].

Likewise, the low participation of domestic investors could be a result of the insufficiency of advisers and lack of investment awareness which called "Herd behavior" which was one of the 2006 domestic crises cause. Domestic investors could be given workshops about securities exchanges. The CMA seeks to raise the level of investment awareness among investors. In line with its ongoing strategy to support and enhance the investor awareness, programs launched in 2006, by establishing an investor education website.

For a flourishing market, it needs to have firm infrastructure, great quality organizations and a well-working supervisory structure. Those things usually were missing in developing markets. Other research focuses to the significance of foreign investment as the supportive to the improvement of the bourses of the emerging markets [8]. Preference for greater accountability for foreign investors will encourage wider adoption of the CMA's code for transparency and disclosure [35].

\section{Conflicts of Interest}

The authors declare no conflicts of interest regarding the publication of this paper.

\section{References}

[1] Capital Market Authority. Investing in the Stock Market. https://cma.org.sa/Awareness/Publications/booklets/Booklet_2.pdf

[2] Alistithmar Capital (2018) Annual Report on the Saudi Stock Market Index: The Impact of the Market Joining Emerging Market Indicators. https://argaamplus.s3.amazonaws.com/d3c17506-0295-4b66-8b02-909d512a9566.p df

[3] Julie Majdalani (2018) Saudi Arabia Joins the MSCI Emerging Markets Index. https://saneoualhadath.me/\%D8\%A3\%D8\%B9\%D9\%85\%D8\%A7\%D9\%84/\%D8\%A 7\%D9\%84\%D8\%B3\%D8\%B9\%D9\%88\%D8\%AF\%D9\%8A\%D8\%A9-\%D8\%AA\%D9 \%86\%D8\%B6\%D9\%85-\%D8\%A5\%D9\%84\%D9\%89-\%D9\%85\%D8\%A4\%D8\%B4\% D8\%B1-msci-\%D9\%84\%D9\%84\%D8\%A3\%D8\%B3\%D9\%88\%D8\%A7\%D9\%82-\% D8\%A7\%D9\%84\%D9\%86\%D8\%A7\%D8\%B4/\#slide-1

[4] Capital Market Authority (2017) Financial Leadership Program: The Capital Market Authority Strategic Plan. https://cma.org.sa/AboutCMA/Documents/Stategy2020_ar.pdf

[5] Ghassan, H. and Alhajhoj, H. (2012) Effect of Capital Market Liberalization on Volatility of TASI. Journal of Development and Economic Policies, 14, 7-39.

[6] Samba Bank (2009) The Saudi Stock Market: Structural Issues, Recent Performance and Outlook. Report Series, December.

[7] Özer, M. and Erdoğan, L. (2006) Türkiye'de İhracat, İthalat ve Ekonomik Büyüme 
Arasındaki İlişkilerin Zamman Serisi Analizi. Ekonomik Yaklaşım, 17, 93-110. https://doi.org/10.5455/ey.10619

[8] Avci, Ö. (2015) Effect of Foreign Investor Transactions on Stock Market Returns. Journal of Economics and Administrative Sciences, 33, 29-38. https://doi.org/10.17065/huiibf.11063

[9] Chan, M. and Kwok, S. (2016) Risk-Sharing, Market Imperfections, Asset Prices: Evidence from China's Stock Market Liberalization. Journal of Banking \& Finance, 84, 166-187. https://doi.org/10.1016/j.jbankfin.2017.06.003

[10] Grosse, R. and Trevino, L.J. (1996) Foreign Direct Investment in the United States: An Analysis by Country of Origin. Journal of International Business Studies, 27, 139-155. https://doi.org/10.1057/palgrave.jibs.8490129

[11] Onyuma, S.O. (2009) Day-of-the-Week and Month-of-the-Year Effect on the Kenyan Stock Market Returns. Eastern Africa Social Science Research Review, 25, 53-74. https://doi.org/10.1353/eas.0.0009

[12] Abdullah, A.M.A. and Ghassan, H.B.A. (2010) Does the Entry of Foreign Investors Influence the Volatility of Doha Securities Market? International Journal of Monetary Economics and Finance, 3, 359-373. https://doi.org/10.1504/IJMEF.2010.035597

[13] Sevil, G., Özer, M. and Kulal,, G. (2012) Foreign Investors and Noise Trade in Istanbul Stock Exchange. Borsa Istanbul Review, 14, 236-241. https://doi.org/10.1016/j.bir.2014.08.001

[14] Rhee, S.G. and Wang, J.X. (2009) Foreign Institutional Ownership and Stock Market Liquidity: Evidence from Indonesia. Journal of Banking \& Finance, 33, 1312-1324. https://doi.org/10.1016/j.jbankfin.2009.01.008

[15] Bitok, J., Kiplangat, A., Tenai, J. and Rono, L. (2011) Determinants of Investor Confidence for Firms Listed at the Nairobi Stock Exchange, Kenya. International Journal of Finance and Management, 1, 160-173.

[16] Froot, K., O'Connell, P. and Seasholes, M. (2001) The Portfolio Flows of International Investors. Journal of Financial Economics, 59, 151-193. https://doi.org/10.1016/S0304-405X(00)00084-2

[17] Inoue, T. (2008) The Causal Relationships in Mean and Variance between Stock Returns and Foreign Institutional Investment in India (Discussion Paper No. 180). Institute of Developing Economies, India.

[18] Cheung, Y.-W. and Ng, L.K. (1996) A Causality-in-Variance Test and Its Application to Financial Market Prices. Journal of Econometrics, 72, 33-48. https://doi.org/10.1016/0304-4076(94)01714-X

[19] Bekaert, G. and Harvey, C. (2000) Foreign Speculators and Emerging Equity Markets. Journal of Finance, 55, 565-614. https://doi.org/10.1111/0022-1082.00220

[20] Karolyi, A. (2002) Did the Asian Financial Crisis Scare Foreign Investors Out of Japan? Pacific-Basin Finance Journal, 10, 411-442. https://doi.org/10.1016/S0927-538X(02)00067-7

[21] Kim, W. and Wei, S.J. (2002) Foreign Portfolio Investors before and during a Crisis. Journal of International Economics, 56, 77-96. https://doi.org/10.1016/S0022-1996(01)00109-X

[22] Dahlquist, M. and Robertsson, G. (2001) Direct Foreign Ownership, Institutional Investors, and Firm Characteristics. Journal of Financial Economics, 59, 413-440. https://doi.org/10.1016/S0304-405X(00)00092-1

[23] Kang, J. and Stulz, R. (1997) Why There Is a Home Bias? An Analysis of Foreign 
Portfolio Equity Ownership in Japan. Journal of Financial Economics, 46, 3-28. https://doi.org/10.1016/S0304-405X(97)00023-8

[24] Choe, Y., Kho, B. and Stulz, R. (1999) Do Foreign Investors Destabilize Stock Markets? The Korean Experience in 1997. Journal of Financial Economics, 54, 227-264. https://doi.org/10.1016/S0304-405X(99)00037-9

[25] Schuppli, M. and Bohl, M.T. (2010) Do Foreign Institutional Investors Destabilize China's A-Share Markets? Journal of International Financial Markets, Institutions and Money, 20, 36-50. https://doi.org/10.1016/j.intfin.2009.10.004

[26] Errunza, V. (2001) Foreign Portfolio Equity Investments, Financial Liberalization, and Economic Development. Review of International Economics, 9, 703-726. https://doi.org/10.1111/1467-9396.00308

[27] Lipsey, R.E. (2001) Foreign Direct Investors in Three Financial Crises. NBER Working Paper No. w8084. https://doi.org/10.3386/w8084

[28] David, P., Yoshikawa, T., Chari, M.D.R. and Rasheed, A.A. (2006) Strategic Investments in Japanese Corporations: Do Foreign Portfolio Owners Foster Underinvestment or Appropriate Investment? Strategic Management Journal, 27, 591-600. https://doi.org/10.1002/smj.523

[29] Kim, I.J., Eppler-kim, J., Kim, W. and Byun, S.J. (2010) Foreign Investors and Corporate Governance in Korea. Pacific-Basin Finance Journal, 18, 390-402. https://doi.org/10.1016/j.pacfin.2010.04.002

[30] Choe, H., Kho, B.C. and Stulz, R.M. (2005) Do Domestic Investors Have an Edge? The Trading Experience of Foreign Investors in Korea. The Review of Financial Studies, 18, 795-829. https://doi.org/10.1093/rfs/hhi028

[31] Vogelvang, B. (2005) Econometrics: Theory and Applications with E-Views. Pearson Education Limited, London.

[32] O’Sullivan, A. and Sheffrin, S.M. (2003) Economics: Principles in Action. Pearson Prentice Hall, Upper Saddle River, 551.

[33] Glynn, J., Perera, N. and Verma, R. (2007) Unit Root Tests and Structural Breaks: A Survey with Applications. Journal of Quantitative Methods for Economics and Business Administration, 3, 63-79.

[34] Ziwot, E. and Andrews, D.W.K. (1992) Further Evidence on the Great Crash, the Oil-Price Shock, and the Unit Root Hypothesis. Journal of Business and Economic Statistics, 10, 251-270. https://doi.org/10.1080/07350015.1992.10509904

[35] Mecca (2018) Money Market Liberalization. https://makkahnewspaper.com/article/857405 